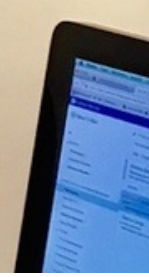

Visit JOSHA at the Frankfurt Book Fair HALL 4.2 Booth A 42

$\begin{aligned} \text { Authors: } & \text { Yaneth Ortiz } \\ \text { Submitted: } & \text { 6. October } 2017 \\ \text { Published: } & 6 \text { October } 2017 \\ \text { Volume: } & 4 \\ \text { Issue: } & 4 \\ \text { Affiliation: } & \text { JOSHA } \\ \text { Keywords: } & \text { Frankfurt, book fair, Buchmesse, } 2017 . \\ \text { DOI: } & 10.17160 \text { /josha.4.4.333 }\end{aligned}$




\section{Visit JOSHA at the Frankfurt book fair}

The Journal of Science, Humanities, and Arts is happy to announce that we will take part at the upcoming Frankfurt Book Fair, opening on October 11th, 2017 at the Frankfurt Trade Fair grounds in Frankfurt am Main, Germany.

The Frankfurt Book Fair is the world's largest trade fair for books, based on both, the number of publishing companies represented, and the number of visitors ${ }^{1}$. It is considered to be the most important book fair in the world for international deals and trading. Publishing-, multimediaand technology companies, as well as content providers from all over the world, gather in this book fair. Publishers, agents, booksellers, librarians, academics, illustrators, service providers, film producers, translators, professional and trade associations, institutions, artists, authors, antiquarians, software and multimedia suppliers all participate in this event. The fair is organised by Frankfurter Buchmesse $\mathrm{GmbH}$. The five-day annual event starts on October $11^{\text {th }}$ and ends on October $15^{\text {th }}, 2017$.

We are very proud of being part of such an important event and share our significant mission with the thousands of visitors that the fair receives every year. We will be showing, for instance, the full features of our software, our current main work, the Demetrios project, and information about the International Academy of Science, Humanities and Arts IAHSA, among others. Come to visit us at stand number 4.2 A 42. We look forward to receiving you at our stand to have interesting interaction, explain you our important work, answer all your questions and get feedback from you that will helps us to improve JOSHA constantly.

\section{Reference}

1. http://www.book-fair.com/fbmsite/en/fbf/press/press-releases/03129/ 